NBER WORKING PAPER SERIES

\title{
THE DISTRIBUTION OF TAX BURDENS: AN INTRODUCTION
}

\author{
Gilbert E. Metcalf \\ Don Fullerton \\ Working Paper 8978 \\ http://www.nber.org/papers/w8978 \\ NATIONAL BUREAU OF ECONOMIC RESEARCH \\ 1050 Massachusetts Avenue \\ Cambridge, MA 02138 \\ June 2002
}

This is an introduction for the forthcoming collection, The Distribution of Tax Burdens, to be published by Edward Elgar Publishing Ltd. We'd like to thank Michael J. Keen, Helen Ladd, and Rob Williams for helpful comments on earlier drafts of this introduction. The views expressed herein are those of the authors and not necessarily those of the National Bureau of Economic Research.

(C) 2002 by Gilbert E. Metcalf and Don Fullerton. All rights reserved. Short sections of text, not to exceed two paragraphs, may be quoted without explicit permission provided that full credit, including $(\mathrm{C}$ notice, is given to the source. 
The Distribution of Tax Burdens: An Introduction

Gilbert E. Metcalf and Don Fullerton

NBER Working Paper No. 8978

June 2002

JEL No. H2, H3

\section{ABSTRACT}

This paper summarizes important developments in tax incidence analysis over the past forty years.

We mark the date of the beginning of modern tax incidence analysis with the publication of Harberger (1962) and discuss the relation of subsequent work to this seminal paper.

Gilbert E. Metcalf

Department of Economics

Tufts University

Medford, MA 02155

and NBER

gilbert.metcalf@tufts.edu
Don Fullerton

Department of Economics

University of Texas

Austin, TX 78712

and NBER

dfullert@eco.utexas.edu 
Tax incidence is the study of who bears the economic burden of a tax. More generally, it is the positive analysis of the impact of taxes on the distribution of welfare within a society. It begins with the very basic insight that the person who has the legal obligation to make a tax payment may not be the person whose welfare is reduced by the existence of the tax. The statutory incidence of a tax refers to the distribution of those legal tax payments - based on the statutory obligation to remit taxes to the government. Thus, for example, the statutory burden of the payroll tax in the United States is shared equally between employers and employees. Economists, quite rightly, focus on the economic incidence, which measures the changes in economic welfare in society arising from a tax. The standard view of the economic incidence of the payroll tax in the United States is that it is borne entirely by employees.

Economic incidence differs from statutory incidence because of changes in behavior and consequent changes in equilibrium prices. Consumers buy less of a taxed product, so firms produce less and buy fewer inputs - which changes the net price or return to each input. Thus the job of the incidence analyst is to determine how those other prices change, and how those price changes affect different groups of individuals.

Across existing studies that analyze distributional effects of taxes, Atkinson and Stiglitz (1980) note that economists have used five different ways of dividing taxpayers into groups. First, some focus on the impact of taxes on consumers as opposed to producers or suppliers of factors (such as labor, capital, and land). A partial equilibrium diagram can identify both the loss of consumer surplus and the loss of producer surplus resulting from a tax. Second, some narrow the focus to analyze the impact of a tax specifically on the relative demands for different factors and the returns to those factors (such as capital, labor, or land). The path-breaking general equilibrium analysis of 
Harberger (1962) simply ignores the consumer side by assuming that everybody spends their money the same way, and then he derives the burden of a sector specific tax on capital as opposed to labor. Third, some studies group individuals or households by some measure of economic well-being. Any such classification then allows the researcher to analyze the progressivity of a tax or tax system (see, for example, Musgrave, Case and Leonard (1974), Devarajan, Fullerton and Musgrave (1980), and Pechman (1985) for early examples using large scale data sets). Typically, taxpayers are grouped by some measure of income, and then the data show how much each group earns from each factor and how much each group spends on each product. Pechman and Okner (1974) is perhaps the classic analysis of the U.S. tax system that groups taxpayers by annual income, while Fullerton and Rogers (1993) group taxpayers by a measure of lifetime resources. Fourth, taxes can be evaluated on the basis of regional incidence. Such analysis might focus on regional differences within a country (e.g. Bull, Hassett and Metcalf (1994)), or it might focus on international differences. Finally, taxes can have intergenerational effects. For example, the creation of a tax and transfer system that is partially or wholly debt funded will bring about a transfer from future generations to members of the current generation (but see Barro (1974) for a dissenting view).

The taxonomy above alludes to partial and general equilibrium analysis. Partial equilibrium analysis focuses on the impact of a tax in one market, ignoring its impact on other markets. It was used by economists long before any of the papers collected in this volume, but it is still appealing because of its analytical tractability and intuition. For example, Figure 1 shows how a tax on a commodity raises the gross-of-tax price to $P_{g}$ and reduces the net price to $P_{n}$. The loss in consumer surplus (the light-shaded area) is larger than the loss in producer surplus (the dark-shaded area), because demand in this 
case is relatively inelastic compared to supply. Also, the commodity in this figure could be labor, in which case the tax is borne more by the firm as the inelastic buyer of labor, compared to the worker as supplier of that labor.

\section{Figure 1: A Simple Partial Equilibrium Model of Tax Incidence}

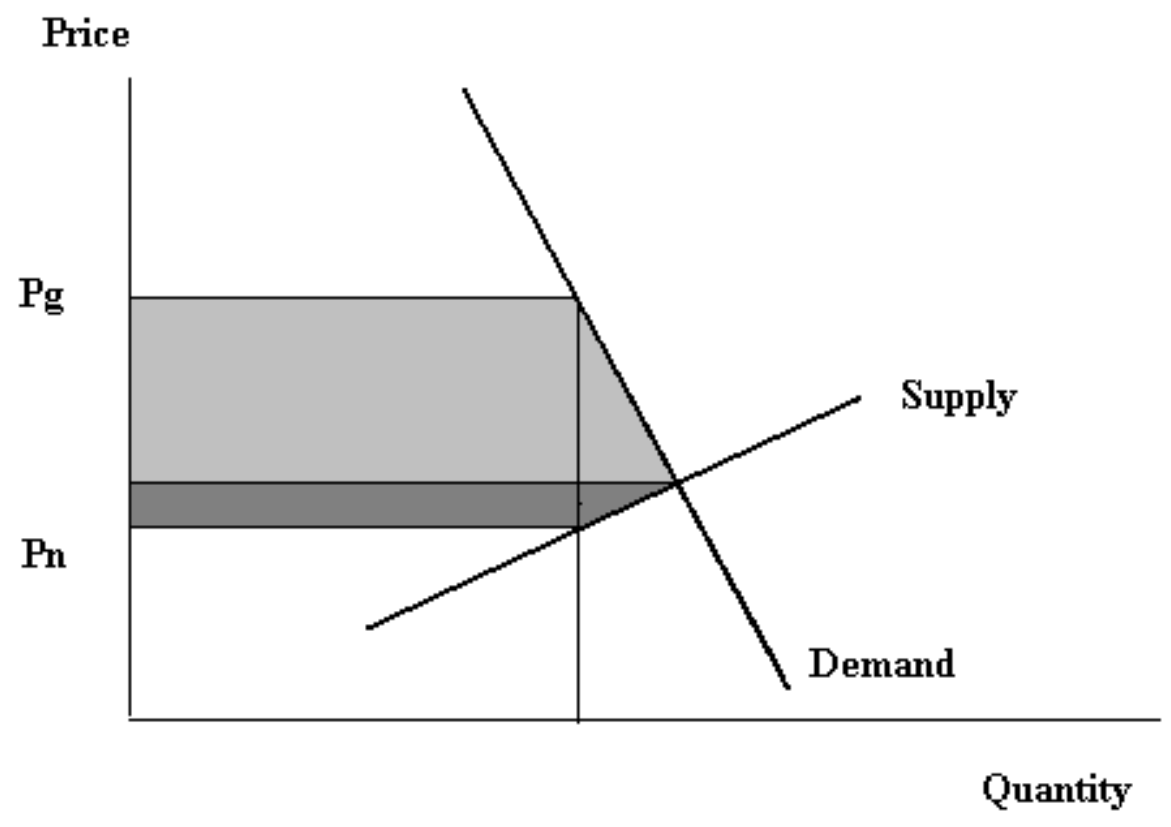

This model does not tell us much about other complicated problems, however, such as the corporate income tax. Thus, modern incidence analysis began with Harberger's (1962) introduction of the general equilibrium model into public finance. A general equilibrium model can be designed to track the impact of a tax from one market to another, accounting for price changes throughout the economy in a way that insures equilibrium in all markets simultaneously. Harberger's original model is a fairly simple representation of an economy with two factors and two products, and it is used to find the 
effects of the corporate income tax on the return to capital relative to the wage rate and the price of corporate output relative to the price of other goods.

We begin this book with Harberger (1962), as the beginning of modern incidence analysis, and we follow it with the diagrammatic exposition of McLure (1974). This first section also includes two early studies that try to employ general equilibrium and other incidence results to guide the use of much data to allocate the burden of all taxes across all households in the United States. Then Section II provides a number of studies that extend this static framework in a number of directions, including more factors, more sectors, other existing taxes, large tax changes, and computational general equilibrium models. Because all those models assume perfect competition, however, Section III backtracks to a partial equilibrium setting in order to look at tax incidence with imperfect competition. We then return to static general equilibrium models in Section IV in order to study the important application of this analysis to property taxation. In Section V, we turn to early dynamic models that allow the analysis of the impact of taxation on savings, investment, and the capital stock. These models in some cases consider transition dynamics as the economy moves from pre-tax to post-tax equilibrium. Finally, in Section VI, we discuss some of the most recent work on lifetime incidence. This work reflects the state of the art in both theoretical and applied incidence analysis.

\section{Early Incidence Theory and Calculations}

Without a doubt, Harberger (1962) is the progenitor of the modern field of general equilibrium incidence analysis. ${ }^{1}$ In addition to providing a framework for analyzing the corporate income tax, Harberger's approach can be used to analyze a wide array of taxes. He models the corporate income tax as a partial factor tax, that is, a tax on the use of one 
factor in one sector. It thus affects relative factor prices and relative output prices. Harberger (1962) not only provides the basic theoretical framework for all general equilibrium tax incidence analysis, he also began the empirical work in this literature. His original paper considers plausible parameter values and likely empirical outcomes. Depending on the empirical assumptions, sometimes capital bears less than the full burden of the corporate income tax, and sometimes it bears more than the full burden of the tax. The main message coming out of this paper, however, is that capital is likely to bear approximately the full burden of the corporate income tax. And capital mobility means that the burden is on all capital, not just corporate capital. Our understanding of Harberger's model has been significantly improved by other papers that we include in this volume. In particular, McLure (1974) provides a very useful graphical exposition that has become standard in the literature.

Included in the first set of papers in this volume are two studies that use insights from both partial and general equilibrium tax incidence theory to derive empirical estimates of the burden of taxes using large-scale data sets. One of the key theoretical insights applied in these studies is that the side of a market that is relatively price inelastic bears a larger burden of the tax than the more price elastic side. Consider, for example, the payroll tax. If the elasticity of labor supply is high relative to the elasticity of labor demand, as drawn in Figure 1 above, then the owners of the firm will bear most of the burden of the tax in the form of lower returns to capital (or else consumers will bear the burden in the form of higher product prices). If labor supply is relatively inelastic, as most economists believe, however, then workers will disproportionately bear the burden of this tax in the form of lower after-tax wages. For excise taxes on output, the standard

\footnotetext{
${ }^{1}$ His is not the first such analysis, however. See, for example, Brown (1939) and Musgrave (1953).
} 
model with constant returns to scale and perfect competition would imply that the supply curve in Figure 1 is flat, and so the burden is fully borne by consumers.

Another key theoretical insight applied in these models is the Harberger result that the corporate income tax is likely to be borne not just by investors in the corporate sector, but by all capital owners. At the same time, Harberger's model can be used to show how the price of corporate output rises relative to the price of non-corporate output, so if all households are not all identical then consumers of corporate output bear disproportionate burdens as well. In addition, McLure's (1974) paper with an immobile factor shows that the tax burden might stay on corporate capital. Thus the issue is not completely settled, as alternative theories still imply alternative results. To apply each of these theories, one needs data on each income group's sources of income and spending on each output.

Pechman and Okner (1974) and Musgrave, et al. (1974) are good examples of this type of analysis. First, they must specify how the burden of each tax is shifted. Then, each scenario is applied to micro-data on households' sources and uses of income. Pechman and Okner merge data files for a sample of 72,000 households. They use information on demographic characteristics such as age and family size, and tax return items such as income from dividends, interest, rent, capital gains, and wages and salaries. They classify households into annual income groups using a measure of economic income that includes transfers, the household's share of corporate retained earnings, and the imputed net rental income from owner-occupied homes. For each set of assumptions about the shifting of each tax, they add up the burdens for each household. Pechman and Okner assume for all cases that the burden of the personal income tax remains with the household, the employee part of the payroll tax remains with the worker, and the burden of sales and excise taxes falls on households according to their consumption patterns. 
The employer share of the payroll tax is sometimes allocated entirely to workers, and it is sometimes allocated equally between workers and consumers. The property tax is assumed to affect either the return to landowners specifically or all capital owners generally. Finally, for the corporate income tax, they consider several cases with different proportions of the burden on shareholders, capital owners, wage-earners, and consumers.

For each combination of assumptions, Pechman and Okner calculate the effective tax rate on each household, defined as the total tax burden as a fraction of economic income. Their results indicate that the most-progressive set of assumptions do not yield results that are markedly different from the least-progressive set of assumptions. In either case, the overall U.S. tax system is roughly proportional over the middle eight deciles. The effective tax rate is higher, however, at the top and bottom tails of the income distribution. At very low-income levels, any positive consumption implies a positive sales tax burden divided by a small income in the denominator. At the other end of the distribution, the rate is high because of the progressive personal income tax and assumed corporate tax burdens from disproportionate holding of corporate stock.

This finding of rough proportionality then helped to shape tax policy debates for the next three decades. The general consensus is that the progressive effects of the personal income tax and the corporate income tax are more-or-less offset by the regressive impacts of payroll taxes, sales taxes, and excise taxes.

Musgrave, et al. (1974) employ similar assumptions and reach similar conclusions, but they also discuss some methodological issues. They show how the 
pattern of effective tax rates depends on the income concept used in the denominator. ${ }^{2}$

They also discuss the importance of the question to be answered (suggesting the use of pre-tax income to calculate the effects of imposing the tax system, but post-tax income to measure the effects of eliminating taxes). Finally, in addition, they proceed to calculate the distributional effects of government spending. They assume that some spending can be allocated, like education spending to families with children in school, and highway spending in proportion to auto expenses. Other spending that cannot be allocated is assumed to benefit families (a.) in proportion to total income, (b.) in proportion to tax burdens, or (c.) on a per capita basis. To varying degrees, all such assumptions yield considerable overall redistribution, with net benefits (after tax burdens) that are positive for the poor and negative for the rich. The rest of this volume focuses only on the distribution of tax burdens.

While those two papers found tax burdens to be roughly proportional over most of the income scale, the next paper in this volume by Browning (1985) finds that the U.S. tax system as a whole is highly progressive. He assumes that sales and excise taxes raise product prices, but government transfers are indexed to provide the same real benefits, thus protecting low-income transfer recipients. Thus these tax burdens do not fall on consumption generally, but only on consumption out of factor income. Even more generally, he points out, the actual indexation of transfers does not matter: the definition

\footnotetext{
${ }^{2}$ The use of money income in the denominator makes the effective tax rates more progressive, because higher income households have a lower denominator while still paying the corporate income tax by assumption, but Musgrave et al. note that "with the entire corporation tax included in the numerator of the effective rate ratio, consistency calls for inclusion of total corporate source income (and not only of dividends) in the denominator" (p.271).
} 
of differential tax incidence holds constant all government expenditures, and constant real government transfers means that the burden of sales taxes must fall on factors. ${ }^{3}$

The approach pioneered by these authors continues to be followed today by many economists inside and outside of government agencies. See, for example, the papers by Dickert, Houser and Scholz (1994), Kasten, Sammartino and Toder (1994), and Gale, Houser and Scholz (1996). This approach also forms the foundation for the distributional analyses undertaken by the U.S. Congressional Budget Office (CBO), the U.S. Department of the Treasury, and the U.K. Office for National Statistics. ${ }^{4}$

\section{General Equilibrium Analysis}

Many economists saw the potential of Harberger's (1962) methodology, and they have been extending it ever since. The first such paper included in this volume is by McLure and Thirsk (1975), who provide a simplified version of the Harberger model that allows incidence to be calculated "on the back of an envelope." This approach uses specific functional forms, which also allows the model to be applied to "large" tax changes (as opposed to Harberger's comparative static approach that only allows analysis of incremental tax changes). In the next paper, Vandendorpe and Friedlaender (1976) extend the original Harberger model by relaxing many of the restrictive assumptions. These assumptions were used by Harberger to obtain tractable formulas, but Vandendorpe and Friedlaender show how to use less restrictive assumptions while still

\footnotetext{
${ }^{3}$ The point about indexation is first made by Browning and Johnson (1979), and the generalization is in the Browning (1985) paper included in this volume.

${ }^{4}$ See Bradford (1995) for a discussion and critique of this type of analysis in the United States. For the United Kingdom, Lakin (2001) reports figures that are very similar in nature to those for the U.S.: "The proportion of gross income paid in direct tax by the top fifth of households is almost double that paid by those in the bottom fifth: 24 per cent compared with 13 per cent. Indirect taxes have the opposite effect to direct taxes taking a higher proportion of income from those with lower incomes" (p.35). We cannot know whether the similarity of results is because of similar methodology or because of similar policies.
} 
obtaining tractable formulas. Whereas Harberger analyzed only a small corporate tax with no other taxes, for example, Vandendorpe and Friedlaender allow for a small change in any large pre-existing tax. The Vandendorpe and Friedlaender analysis is quite interesting because of the extent to which they can elaborate the Harberger model without becoming overwhelmed by messy and intractable formulas.

General equilibrium models have been used in other contexts. A basic finding from partial equilibrium analysis is that any inelastically-supplied factor of production bears the full burden of a tax on that factor. Because land is inelastically supplied, economists presume that a tax on land is borne by the landowner. Feldstein (1977) reverses that result in a model where land serves not only as a factor of production but also as an asset. A tax on land rent then induces investors to increase holdings of other assets in their portfolios. The resulting increase in reproducible, physical capital can then lead to an increase in the wage rate and a decrease in the return to physical capital. Hence, part of the tax on land rent is shifted to capital, with wage rates rising in response to the greater capital-labor ratio.

In another counterintuitive paper included in this volume, Bradford (1978) reverses the common presumption that international mobility of capital yields an elastic supply of capital at a fixed world rate of return, and so capital cannot bear the burden of a local tax on capital. Bradford shows that capital does indeed bear the burden of a local tax on capital, in the aggregate. The tax burden is not on local investors but is spread across all investors worldwide.

The analytical general equilibrium literature following Harberger (1962) grew exponentially, as did the accessibility and power of computers, which together engendered a large and important literature in computable general equilibrium analysis. 
Economists then showed how computers could be used to solve large and complex general equilibrium models, and hence to provide analyses of more realistic tax systems. One of the early and important papers in this literature is Shoven (1976), which we present in this volume. ${ }^{5}$ Whereas Harberger analyzed a small tax change for two sectors, Shoven's computational model analyzes a large corporate tax and provides detailed results for twelve sectors. Still, however, he shows that a two-sector aggregation of his model provides results that are very similar to Harberger's. We also include a paper by Devarajan, et al. (1980) that compares the Pechman and Musgrave, et al. (1974) approach to results from a computable general equilibrium model. They find that the Pechman and Musgrave approach nicely approximates the computational model except to the extent that output is produced using factors in proportions that are far different from the average, or to the extent that certain groups receive income from factors in proportions that are far different from the average.

\section{Incidence with Imperfect Competition}

The models discussed above assume that markets are perfectly competitive. While many of the insights from this literature carry over to models with imperfectly competitive markets, some important differences arise. For example, when markets are perfectly competitive, unit taxes and ad valorem taxes have the same incidence impact (when the two types of tax rates are set to collect the same amount of revenue). Bishop (1968) carried out an early analysis of ad valorem and unit taxes under monopoly, building on earlier work by Suits and Musgrave (1953). As Bishop's paper in this volume shows, the two types of taxes lead to different equilibria in the presence of a

\footnotetext{
${ }^{5}$ See Shoven and Whalley (1984) for a history of the development of this literature.
} 
monopolist. This difference raises the possibility of "over-shifting," which occurs when the consumer price rises by more than the tax (in the case of a commodity tax).

Models of tax incidence in oligopolistic markets began to appear in the early 1980s. The paper by Kay and Keen (1983) in this volume introduces taxes into the circular location model of Salop (1979). With oligopolistic markets, consumer welfare can be affected by mechanisms other than changes in price and quantity. If consumers value product diversity, part of the burden of the tax can be felt in the form of reduced utility from reduced equilibrium product variety. The Kay and Keen model illustrates this clearly. The next two papers in the volume analyze tax incidence in models with homogenous goods and Cournot-Nash oligopolies. Katz and Rosen (1985) make the important point that results from this type of model do not lie between those of perfect competition and monopoly models. Indeed, it is not appropriate to view perfect competition and monopolies as polar extremes, as if oligopolistic markets' responses to taxes were some weighted average of the two. Like Katz and Rosen, Stern (1987) extends the analysis to consider models with a fixed number of firms, but then he also considers free-entry oligopolies (or "monopolistic competition" in Stern's vocabulary). His paper extends important work on tax incidence in oligopolistic markets by Seade $(1985)^{6}$

Building on Stern's model, Delipalla and Keen (1992) extend the analyses of Suits and Musgrave and Bishop to compare and contrast ad valorem and unit taxes in oligopolistic markets. We include this paper here, as it brings together a number of strands of incidence analysis (such as market structure and instrument choice) that have been explored separately in the various papers described above.

\footnotetext{
6 See also Besley (1989) and Besley and Suzumura (1992) for further elaboration of these models.
} 


\section{Property Taxation}

General equilibrium analysis has radically changed economists' thinking about the incidence of property taxes. We begin with a paper by Mieszkowski (1972) that recounts and reconciles alternative views. First, the property tax has been viewed as an excise tax on housing services that is regressive because housing expenditures are a high proportion of low-income budgets. This "old view" is typically associated with Simon (1943), but it dates back to Edgeworth (1897). Second, the property tax has been viewed as a profits tax on capital income that is progressive because capital is a high proportion of highincome sources. This view is called the "new view," although it originates with Brown (1924). Perhaps it is new relative to Edgeworth (1897)! ${ }^{7}$

Mieszkowski's contribution is to reconcile these views in a Harberger general equilibrium modeling framework. If $\tau_{i}$ is the tax rate on property in community $i$, we can decompose the rate into two components as $\tau_{i}=\bar{\tau}+\varepsilon_{i}$ where $\bar{\tau}$ is the average property tax rate over the entire country, and $\varepsilon_{i}$ is the deviation of the local rate from the national average. By construction, the average of $\varepsilon_{i}$ across all communities is zero. Mieszkowski argues that the first component of $\tau_{i}$ can be viewed as a national tax on housing capital at rate $\bar{\tau}$. Using the Harberger framework, he then argues that this tax burdens all capital. The second component, Mieszkowski continues, can be viewed as a differential tax that can be positive or negative. This differential tax might be passed forward to consumers of housing or passed backwards to immobile factors (workers or

\footnotetext{
${ }^{7}$ The property tax has also been viewed as a tax on site rents that is shifted to landowners. Marshall (1890) provides an early statement of this "classical" view, but Simon (1943) points out that classical economists divide the property tax into a portion falling on land rents and a portion falling on improvements.
} 
landowners). Mieszkowski concludes that the bulk of this differential tax is passed forward to consumers.

Even in Mieszkowski's model, note that the regressivity of the tax depends on what sort of tax change is contemplated. A uniform nation-wide increase in property tax would impact capital income, which is progressive under the "new" view. In contrast, a single community's increase in property tax would likely raise that town's cost of housing, which is regressive under the "old" view.

We next include two papers by Musgrave (1974) and Aaron (1974), as they bring a great deal of information about housing markets to bear on the Harberger-style analysis in Mieszkowski (1972). Musgrave generally supports the old view. He notes, for example, that many rental markets in urban areas are likely to be imperfectly competitive. Thus, some of the insights from the papers in Section III of this book may be useful for thinking about property tax incidence. Aaron generally supports the new view. He notes that, even under the old view, the portion of the property tax falling on rental housing may well be progressive since the ratio of market value to rent rises with rent (more expensive houses have relatively low monthly rent). These two papers point to the importance of attention to institutional detail when undertaking incidence analyses.

Next, we include a paper by Hamilton (1976) that articulates a third view, called the "benefit" view, that the property tax is neither regressive nor progressive because it is really no tax at all. ${ }^{8}$ Building on Tiebout (1956), Hamilton argues that mobile taxpayers would not live in any jurisdiction that charges a tax higher than the value of its local public goods and services - unless property values adjusted to reflect the differential between the value of services received and taxes paid (the "fiscal surplus"). In other 
words, house prices would rise by the capitalized value of any positive stream of fiscal surpluses or fall by the capitalized value of any negative stream (where taxes exceed local services). If the local property tax becomes a voluntary price paid for those local goods and services, then it is no tax at all. Thus, we have the "old" view, the "new" view, and the "no" view of the property tax. ${ }^{9}$

Hamilton's focus is on the efficiency impact of property taxes. He argues that the property tax per se has no distributional impact because of capitalization. His story is not complete yet, as he notes that the value of land is higher when used to construct housing that is below the average value of housing in the community. Because the property tax on such a house would be less than the (uniform) services provided, the fiscal surplus for such a house will be positive, and the landowner can extract those rents when selling the site. This shift in the mix of housing will lead to a shift in the burden of the property tax from owners of below-average-value housing to owners of above-average-value housing. In response, a countervailing political force will limit this shift (zoning or some other form of regulation). The outcome of this political process cannot be predicted in an economic model, and zoning could be so restrictive as to limit the amount of low-value housing to levels that are inefficient (and that lead to a shift of the burden of property tax from high-value homeowners to low-value homeowners). Hamilton concludes that it is impossible to determine the incidence of property taxes until we have a better understanding of the political forces influencing land-use policy.

Finally, we present a paper by Oates (1969) that first attempts to measure empirically the degree of capitalization of property taxes into property values. Testing

\footnotetext{
${ }^{8}$ This argument is first articulated in Hamilton (1975), but we include Hamilton (1976) because it extends the argument to allow for heterogeneous communities.

${ }^{9}$ Zodrow (2001) provides a possible reconciliation of these various views.
} 
empirically the degree of tax capitalization turns out to be a complicated statistical exercise, and economists continue to disagree as to the degree of capitalization. Many economists believe that the benefit view should imply complete capitalization of property taxes (holding public services and other amenities constant). If so, then perhaps an empirical test of capitalization could help us choose between the new and benefit views. Alas, Mieszkowski and Zodrow (1989) point out that property taxes may be capitalized under both the benefit view and the new view. Thus, while capitalization is an important phenomenon in tax incidence theory, it is not useful for sorting out the various views of the property tax.

\section{Incidence in Dynamic Models}

Up to this point, we have ignored the impact of taxes on saving and investment. We need models with intertemporal optimization to allow for endogenous saving and investment. The essential engine of long-run incidence in these models is the impact of taxes on capital-labor ratios (and thus factor prices). We shall also see, however, that inelastic capital supply in the short-run plays an important role through asset price revaluations in response to tax policy. Anticipations also become important.

We first present a paper by Feldstein (1974) that develops a neoclassical growth model to analyze the long-run incidence of a tax on capital income. Feldstein concludes that much (if not all) of the burden of the tax is shifted to workers in the form of lower wages resulting from a decline in the capital-labor ratio. The conclusions from this model are particularly stark in a two-class world in which all savings is from capital income only. In this case, the entire capital income tax is borne by workers in the form of lower wages. 
Feldstein compares steady-state equilibria. However, the transition from the old to the new steady-state equilibrium could take many years, and welfare impacts of a tax change during the transition could be quite different from those in the new steady state. We include a paper by Bernheim (1981) that provides a way to think about the welfare impact of a tax change along the entire path from old to new equilibrium. ${ }^{10}$

In general, a complete picture of the burden of a capital income tax in a neoclassical growth model such as Feldstein's would require the analyst to discount and add up the workers' gains and losses over time. One simple way to measure the burden shift would be to compute the present discounted value of the change in wage income assuming some given discount rate. We note four problems with this approach. First, the discount rate in this approach is exogenous but instead should be linked to consumer preferences. Second, it would be preferable to have some dynamic measure of compensating or equivalent variation for the tax shift. Third, the savings rate in this model does not follow from consumer preferences. Fourth, the savings rate depends only on current information with no anticipations.

The switch from neoclassical growth model to life-cycle model can help solve several of these problems. The first major life-cycle model we include is by Summers (1981). He adds capital income taxation to the standard life-cycle model and argues that traditional measures of the interest elasticity of savings are seriously understated. This paper dramatically alters the incidence and welfare impacts of capital income taxation. It does not include perfect foresight, however, which is the major contribution of the next life-cycle model we include by Auerbach, Kotlikoff and Skinner (1983). They build an overlapping generations (OLG) computable general equilibrium (CGE) model of an

\footnotetext{
${ }^{10}$ Also, see Boadway (1979) for a discussion of the Feldstein model along the transition.
} 
economy with a representative agent in each cohort, and they use consumer preferences to calculate the effects of a tax change on savings behavior. They calculate not just the discounted present value of gains and losses, but lifetime equivalent variations using the consumer's own rate of time preference. They show effects on those who are old or young at the time of the tax change, as well as those not yet born. Thus, this model and its subsequent variants are very useful for understanding the inter-generational incidence of government policies.

If the life-cycle model includes the possibility that utility can be derived from the well-being of one's own children, then we have the infinite-life model. This model can also solve the four problems listed above, including the use of consumer preferences to calculate endogenous savings and equivalent variations. We next present an infinite-life model by Judd (1985) that also calculates the effects of anticipations. Consider, for example, the announcement today of a temporary surtax on capital income for ten years that will begin five years from now. This announcement itself, if credible, should have an impact on capital accumulation over the next five years - before the tax is actually changed.

In the Judd (1985) paper, capital accumulation depends on preferences and, in particular, the concavity of the utility function. Costs of adjusting the capital stock play no role. More generally, however, firms might well incur significant costs during the process of major investment projects. The next paper in this volume, by Summers (1985), presents a simple partial equilibrium model to illustrate how corporate tax policy can affect investment as well as the market value of capital in place. 


\section{Lifetime Tax Incidence}

In the last section of this volume, we turn to an area that has seen a burst of research activity in the past few years. Following the data-intensive exercises of Pechman and Okner (1974) and Musgrave, et al. (1974) that classified households by annual income, many economists noted that annual income is not necessarily a good measure of one's overall level of well-being, for several reasons. The low-annual-income group may include four very different kinds of individuals: those with volatile annual income who merely had a bad year, those who are young and just beginning a highincome career, those who are old and just finished a high-income career, and those who are truly poor. To the extent that the tax burden for this aggregation is high or low, the implications for policy are unclear. Instead, the identification of those who are truly poor requires a more permanent measure of income such as "lifetime income", the present value of all wages plus inheritances.

An initial approach to this problem by Davies, St Hilaire and Whalley (1984) in this volume captures lifetime income heterogeneity using a data-intensive exercise with incidence assumptions in the style of Pechman and Okner (1974). They find that a progressive tax like the personal income tax is not as progressive on a lifetime basis because high-income years with high taxes are added together with the same individual's low-income years and low taxes. For similar reasons, regressive taxes like sales and excise taxes are not as regressive on a lifetime basis. When all taxes are added together, the overall tax system is roughly proportional, just as in Pechman and Okner (1974).

Empirical incidence analyses from a lifetime perspective suffer from the lack of data on the entire lifetime income and consumption patterns of households. Thus, any attempt to apply the lifetime approach requires heroic assumptions. In the Davies et al. 
model, for example, all income streams are exogenous and the consumption path is based on an additive isoelastic utility function. Interest and growth rates are predetermined based on Canadian data, and the model is then used to calculate life-cycle consumption, income, tax payments, and government transfers. Other empirical studies use annual data to construct a proxy for lifetime income. We next include a paper by Poterba (1989) that invokes the Modigliani and Brumberg (1954) consumption-smoothing story to study U.S. federal excise taxes. With perfect life-cycle consumption smoothing, and with individuals identical except for lifetime income levels, current consumption is proportional to lifetime income. Thus, Poterba can use data on one year's consumption to categorize individuals by lifetime income. ${ }^{11}$ We also include a paper by Caspersen and Metcalf (1994) to illustrate the advances that follow the Poterba analysis.

Computable general equilibrium models also have been used to consider the lifetime incidence of taxes. Such a model can track a household over its entire economic life, tracing income and consumption paths as well as all taxes paid in each period. As mentioned above, Auerbach, et al. (1983) use a CGE model with life-cycle savings behavior of one representative agent in each cohort. This model is very useful for intergenerational incidence, but it cannot be used to study intra-generational redistribution between rich and poor. In contrast, other CGE models following Shoven (1976) can study redistribution between rich and poor on the basis of annual income but do not incorporate life-cycle behavior. Thus, the major goal of the book by Fullerton and Rogers (1993) is to combine the best of both worlds: life-cycle decision-making of

\footnotetext{
${ }^{11}$ Metcalf (1994) applies a similar idea to the system of state and local sales taxes in the United States and finds that a case can be made for viewing this system of taxes as progressive, contrary to accepted wisdom. The shift to a lifetime perspective is one important factor blunting the regressivity of state and local sales taxes. In addition, most states exempt a variety of goods with low income elasticities, thereby adding to the progressivity of the system.
} 
households arrayed from rich to poor on the basis of lifetime income. In other words, they incorporate heterogeneity both in terms of age and in terms of lifetime income. Some of the initial results of that book are summarized in the paper by Fullerton and Rogers (1991) that is included in this volume. Also, this paper includes a table showing for each annual income decile how many individuals are estimated to be in each lifetime income decile. The diagonal of this matrix shows that only about 20 percent of individuals are in the same decile by both measures.

Finally, we include a recent paper by Altig, Auerbach, Kotlikoff, Smetters and Walliser (2001) that represents the state-of-the-art as of the publication of this volume (2002). They build upon both the perfect foresight life-cycle model of Auerbach, et al. (1983) and the 12 lifetime-income groups of Fullerton and Rogers (1993). They trace transition paths as well as steady-state allocations, and they calculate the incidence of several fundamental tax reform proposals. The switch to a flat tax does indeed reduce overall progressivity, even on a lifetime basis, unless it is combined with sizeable exemptions. Thus taxes still have major potential for redistribution, not just explicitly through changes in tax liabilities but also implicitly through price changes.

\section{Conclusion}

Tax incidence is one of the central topics in public finance, and our understanding of the concept has improved dramatically in this century. We have deliberately chosen to include works only from the past forty years, even though other classic contributions date back nearly two hundred years (see, for example, Cournot (1838)).

The papers in this volume are classics in the field while continuing to be important references for modern researchers. Even the first paper included here by Harberger (1962) still provides the foundation for general equilibrium incidence, whether 
through calculations of CGE models or through the intuition of analytical models.

Imperfect competition will remain an important topic as firms continue to merge in this new century, and capitalization effects will remain important as new tax proposals are announced and enacted.

In fact, we believe that both annual and lifetime incidence analysis will remain important, as imperfect borrowing constraints mean that annual income is still relevant to any individual who cannot borrow against future lifetime income. Thus we are confident that the papers included in this volume will stand the test of time. 


\section{References}

Aaron, Henry J. "A New View of Property Tax Incidence." American Economic Review, 1974, 64(2), pp. 212-21.

Altig, David; Auerbach, Alan J.; Kotlikoff, Laurence J.; Smetters, Kent A. and Walliser, Jan. "Simulating Fundamental Tax Reform in the United States." American Economic Review, 2001, 91(3), pp. 574-95.

Atkinson, Anthony B. and Stiglitz, Joseph E. Lectures on Public Economics. New York: McGraw-Hill, 1980.

Auerbach, Alan J.; Kotlikoff, Laurence J. and Skinner, Jonathan. "The Efficiency Gains from Dynamic Tax Reform." International Economic Review, 1983, 24(1), pp. 81-100.

Barro, Robert J. "Are Government Bonds Net Wealth?" Journal of Political Economy, 1974, 82, pp. 1095-117.

Bernheim, B. Douglas. "A Note on Dynamic Tax Incidence." Quarterly Journal of Economics, 1981, 96(4), pp. 705-23.

Besley, Timothy. "Commodity Taxation and Imperfect Competition: A Note on the Effects of Entry." Journal of Public Economics, 1989, 40(3), pp. 359-67.

Besley, Timothy and Suzumura, Kotaro. "Taxation and Welfare in an Oligopoly with Strategic Commitment." International Economic Review, 1992, 33(2), pp. 413-31.

Bishop, Robert L. "The Effects of Specific and Ad Valorem Taxes." Quarterly Journal of Economics, 1968, 82(2), pp. 198-218.

Boadway, Robin. "Long-Run Tax Incidence: A Comparative Dynamic Approach." Review of Economic Studies, 1979, 46(3), pp. 505-11.

Bradford, David F. "Factor Prices May Be Constant but Factor Returns Are Not." Economics Letters, 1978, 1(3), pp. 199-203.

ed. Distributional Analysis of Tax Policy. Washington, DC: American Enterprise Institute, 1995.

Brown, Harry Gunnison. The Economics of Taxation. New York: Holt, 1924.

. "The Incidence of a General Output or a General Sales Tax." Journal of Political Economy, 1939, 47(2), pp. 254-62.

Browning, Edgar K. "Tax Incidence, Indirect Taxes, and Transfers." National Tax Journal, 1985, 38(4), pp. 525-33. 
Browning, Edgar K. and Johnson, William R. The Distribution of the Tax Burden. Washington, DC: American Enterprise Institute, 1979.

Bull, Nicholas; Hassett, Kevin A. and Metcalf, Gilbert E. "Who Pays Broad-Based Energy Taxes? Computing Lifetime and Regional Incidence." Energy Journal, 1994, 15(3), pp. 145-64.

Caspersen, Erik and Metcalf, Gilbert E. "Is a Value Added Tax Regressive? Annual Versus Lifetime Incidence Measures." National Tax Journal, 1994, 47(4), pp. 731-46.

Cournot, Antoine Augustin. Researches into the Mathematical Principles of the Theory of Wealth. New York: Macmillan, 1838, This edition published 1897.

Davies, James B.; St Hilaire, France and Whalley, John. "Some Calculations of Lifetime Tax Incidence." American Economic Review, 1984, 74(4), pp. 633-49.

Delipalla, Sofia and Keen, Michael. "The Comparison between Ad Valorem and Specific Taxation under Imperfect Competition." Journal of Public Economics, 1992, 49(3), pp. 351-67.

Devarajan, Shantayanan; Fullerton, Don and Musgrave, Richard A. "Estimating the Distribution of Tax Burdens: A Comparison of Different Approaches." Journal of Public Economics, 1980, 13(2), pp. 155-82.

Dickert, Stacy; Houser, Scott and Scholz, John Karl. "Taxes and the Poor: A Microsimulation Study of Implicit and Explicit Taxes." National Tax Journal, 1994, 47(3), pp. 621-38.

Edgeworth, F.Y. "The Pure Theory of Taxation." The Economic Journal, 1897, 7(25), pp. 46-70.

Feldstein, Martin. "Incidence of a Capital Income Tax in a Growing Economy with Variable Savings Rates." Review of Economic Studies, 1974, 41(4), pp. 505-13.

- "The Surprising Incidence of a Tax on Pure Rent: A New Answer to an Old Question." Journal of Political Economy, 1977, 85(2), pp. 349-60.

Fullerton, Don and Rogers, Diane Lim. "Lifetime Versus Annual Perspectives on Tax Incidence." National Tax Journal, 1991, 44(3), pp. 277-87.

- Who Bears the Lifetime Tax Burden? Washington, DC: Brookings Institution, 1993.

Gale, William; Houser, Scott and Scholz, J. Karl. "Distributional Effects of Fundamental Tax Reform," H. Aaron and W. Gale, Economic Effects of Fundamental Tax Reform. Washington, DC: Brookings Institution, 1996, pp. 281315. 
Hamilton, Bruce W. "Zoning and Property Taxation in a System of Local Governments." Urban Studies, 1975, 12, pp. 205-11.

- "Capitalization of Intrajurisdictional Differences in Local Tax Prices." American Economic Review, 1976, 66, pp. 743-53.

Harberger, Arnold C. "The Incidence of the Corporation Income Tax." Journal of Political Economy, 1962, 70(3), pp. 215-40.

Judd, Kenneth L. "Redistributive Taxation in a Simple Perfect Foresight Model." Journal of Public Economics, 1985, 28(1), pp. 59-83.

Kasten, Richard; Sammartino, Frank and Toder, Eric. "Trends in Federal Tax Progressivity, 1980-93," J. Slemrod, Tax Progressivity and Income Inequality. Cambridge: Cambridge University Press, 1994, pp. 9-50.

Katz, Michael and Rosen, Harvey S. "Tax Analysis in an Oligopoly Model." Public Finance Quarterly, 1985, 13(1), pp. 3-19.

Kay, John A. and Keen, Michael J. "How Should Commodities Be Taxed?" European Economic Review, 1983, 23(3), pp. 339-58.

Lakin, Caroline. "The Effects of Taxes and Benefits on Household Income, 1999-2000." Economic Trends, 2001, (569), pp. 35-74.

Marshall, Alfred. Principles of Economics. London: Macmillan and Co., 1890.

McLure, Charles E., Jr. "A Diagrammatic Exposition of the Harberger Model with One Immobile Factor." Journal of Political Economy, 1974, 82(1), pp. 56-82.

McLure, Charles E., Jr. and Thirsk, Wayne R. "A Simplified Exposition of the Harberger Model, I: Tax Incidence." National Tax Journal, 1975, 28(1), pp. 1-27.

Metcalf, Gilbert E. "The Lifetime Incidence of State and Local Taxes: Measuring Changes During the 1980s," J. Slemrod, Tax Progressivity and Income Inequality. Cambridge: Cambridge University Press, 1994, pp. 59-88.

Mieszkowski, Peter M. "The Property Tax: An Excise Tax or a Profits Tax?" Journal of Public Economics, 1972, 1(1), pp. 73-96.

Mieszkowski, Peter and Zodrow, George R. "Taxation and the Tiebout Model: The Differential Effects of Head Taxes, Taxes on Land Rents and Property Taxes." Journal of Economic Literature, 1989, 27(3), pp. 1098-146.

Modigliani, Franco and Brumberg, Richard. "Utility Analysis and the Consumption Function: An Interpretation of Cross-Section Data," K. K. Kurihara, Post- 
Keynesian Economics. New Brunswick: Rutgers University Press, 1954, pp. 388436.

Musgrave, Richard A. "On Incidence." Journal of Political Economy, 1953, 61(4), pp. 306-23.

. "Is a Property Tax on Housing Regressive?" American Economic Review, 1974, 64(2), pp. 222-29.

Musgrave, Richard A.; Case, Karl E. and Leonard, Herman. "The Distribution of Fiscal Burdens and Benefits." Public Finance Quarterly, 1974, 2, pp. 259-311.

Oates, Wallace E. "The Effects of Property Taxes and Local Public Spending on Property Values: An Empirical Study of Tax Capitalization and the Tiebout Hypothesis." Journal of Political Economy, 1969, 77(6), pp. 957-71.

Pechman, J. Who Paid the Taxes: 1966-85? Washington DC: Brookings, 1985.

Pechman, Joseph A. and Okner, Benjamin A. Who Bears the Tax Burden? Washington, DC: Brookings Institution, 1974.

Poterba, James. "Lifetime Incidence and the Distributional Burden of Excise Taxes." American Economic Review, 1989, 79(2), pp. 325-30.

Salop, Steven C. "Monopolistic Competition with Outside Goods." Bell Journal of Economics, 1979, 10, pp. 141-56.

Seade, Jesus E. "Profitable Cost Increases and the Shifting of Taxation: Equilibrium Responses of Markets in Oligopoly," Working Paper No. 260, Warwick: University of Warwick, 1985.

Shoven, John B. "The Incidence and Efficiency Effects of Taxes on Income from Capital." Journal of Political Economy, 1976, 84(6), pp. 1261-83.

Shoven, John B. and Whalley, John. "Applied General Equilibrium Models of Taxation and International Trade: An Introduction and Survey." Journal of Economic Literature, 1984, 22(3), pp. 1007-51.

Simon, Herbert A. "The Incidence of a Tax on Urban Real Property." Quarterly Journal of Economics, 1943, 59(3), pp. 398-420.

Stern, Nicholas. "The Effects of Taxation, Price Control and Government Contracts in Oligopoly and Monopolistic Competition." Journal of Public Economics, 1987, 32, pp. 133-58.

Suits, Daniel B. and Musgrave, Richard A. "Ad Valorem and Unit Taxes Compared." Quarterly Journal of Economics, 1953, 67(4), pp. 598-604. 
Summers, Lawrence H. "Capital Taxation and Accumulation in a Life Cycle Growth Model." American Economic Review, 1981, 71(4), pp. 533-44.

- "The Asset Price Approach to the Analysis of Capital Income Taxation," G. R. Feiwil, Issues in Contemporary Macroeconomics and Distribution. London: Macmillan, 1985, pp. 429-43.

Tiebout, Charles M. "A Pure Theory of Local Expenditures." Journal of Political Economy, 1956, 64, pp. 416-24.

Vandendorpe, Adolf L. and Friedlaender, Ann F. "Differential Incidence in the Presence of Initial Distorting Taxes." Journal of Public Economics, 1976, 6(3), pp. 205-29.

Zodrow, George. "The Property Tax as a Capital Tax: A Room with Three Views." National Tax Journal, 2001, 54(1), pp. 139-56. 